\title{
KETERAMPILAN SOSIAL SISWA DALAM PEMBELAJARAN FISIKA SMP MELALUI PENERAPAN MODEL PEMBELAJARAN INDUKTIF
}

\author{
Dodi Dahnuss $^{1 *}$, Okta Alpindo ${ }^{2}$ \\ ${ }^{1,2}$ Universitas Maritim Raja Ali Haji, Tanjungpinang, Kepulauan Riau 29124, Indonesia \\ Pengiriman: 21 Februari 2019; Diterima: 26 Februari 2019; Publikasi: 28 Juli 2019
}

\begin{abstract}
Abstrak
Penelitian ini bertujuan untuk mendeskripsikan keterampilan sosial siswa dalam pembelajaran fisika melalui penerapan model pembelajaran induktif pada materi Cahaya di Kelas VIII SMP Negeri 4 Tambang Tahun Pelajaran 2010/2011. Subjek penelitian ini adalah siswa kelas VIII.a yang berjumlah 34 orang. Instrumen pengumpulan data penelitian adalah lembar pengamatan keterampilan sosial. Teknik pengumpulan data adalah dengan melakukan pengamatan terhadap keterampilan sosial siswa selama proses pembelajaran berlangsung. Teknik analisis data menggunakan teknik deskriptif yang meliputi 4 indikator yaitu bekerjasama, menyampaikan pendapat, menanggapi pendapat dan mendengarkan dengan aktif. Hasil analisis data menunjukan bahwa indikator bekerjasama $(97,15 \%)$ kategori tinggi, menyampaikan pendapat $(81,31 \%)$ kategori tinggi, menanggapi pendapat $(58,51 \%)$ kategori sedang, dan mendengarkan dengan aktif $(86,92 \%)$ kategori tinggi. Dengan demikian, penerapan model induktif dapat melatih keterampilan sosial siswa di SMP negeri 4 tambang pada materi pokok cahaya.
\end{abstract}

Kata kunci: keterampilan sosial; model induktif; fisika.

\begin{abstract}
The purpose of this research was to describe students' social skills as the impact of inductive instructional model implementation in physic course at SMP Negeri 4 Tambang. The research participants consisted of 34 students of grade 8 . In taking the data, observation was used. The data were analyzed by using descriptive technique based on the indicators of the social skill itself. It was found that the student's skill in cooperative learning was $97.15 \%$, the student's skill in giving opinion was $81.31 \%$, student's skill in giving argument was $58.51 \%$, student's skill in listening comprehension was $86.92 \%$. finally inductive instructional model trained student's social skill.
\end{abstract}

Keywords: social skill; inductive model; physic

\section{PENDAHULUAN}

Kemajuan ilmu pengetahuan dan teknologi yang sangat pesat sekarang ini menjadikan dunia pendidikan harus mendapatkan perhatian khusus. Sebab antara ilmu pengetahuan dan teknologi mempunyai hubungan timbal balik. Majunya ilmu pengetahuan akan membuahkan teknologi yang lebih maju.
Untuk menunjang mutu pendidikan pemerintah mengembangkan sistem penjaminan mutu melalui standarisasi, akreditasi dan sertifikasi di bidang pendidikan, baik formal maupun nonformal. Untuk standarisasi pendidikan pemerintah telah mengeluarkan Peraturan Pemerintah (PP) Nomor 19 Tahun 2005 tentang Standar Nasional Pendidikan (SNP) yang telah 


\section{JURNAL KIPRAH, Juli 2018; VI1(1): 27-31 \\ e-ISSN: 2580-6947 \\ p-ISSN: 2354-7278}

mengatur garis-garis besar mengenai berbagai aspek standar mutu pendidikan, yang meliputi: standar proses, standar isi, standar kempetensi lulusan, standar sarana prasarana, standar pembiayaan, standar pengelolaan, standar pendidik dan tenaga kependidikan, serta standar penilaian pendidikan.

Pelajaran fisika merupakan hasil kegiatan manusia berupa pengetahuan, gagasan dan konsep yang terorganisasi tentang alam sekitarnya yang diperoleh melalui serangkaian proses ilmiah. Pelajaran sains merupakan salah satu pelajaran IPA yang titik beratnya adalah eksperimentasi, sehingga disarankan agar dalam pembelajaran digunakan pendekatan yang menghendaki siswa menemukan kembali atau merekontruksi kebenaran-kebenaran yang harus dipelajari. Pelajaran fisika memberi peluang bagi terbentuknya kemampuan berfikir, berkomunikasi, bernalar secara efektif dan efisien serta membentuk sikap positif untuk menghadapi perubahan keadaan yang selalu berkembang pesat.

Secara garis besar keterampilan sosial diartikan sebagai keterampilan berkomunikasi dan berinteraksi dengan orang lain. Terdapat juga ahli yang menyamakan keterampilan sosial dengan kecerdasan emosional. Dalam taksonomi tujuan pembelajaran, keterampilan sosial (kecerdasan emosional) termasuk ke dalam ranah afektif (Anderson, 2010). Keterampilan sosial merupakan bentuk hasil belajar yang ditandai dengan kemampuan seseorang untuk berinteraksi dengan orang lain (keterampilan interpersonal). Keterampilan sosial ini juga disebut keterampilan kooperatif, salah satu contoh dari keterampilan sosial ini misalnya kemampuan bekerja sama, kemampuan menjadi pendengar yang baik, keterampilan berbagi tugas dengan teman dan sebagainya. Selama ini pula kebanyakan sekolah lebih memfokuskan perhatian pada ranah kognitif siswa, jarang sekali sekolah yang secara serius menggarap sisi afektif.

Salah satu permasalahan yang peneliti temukan saat melakukan observasi awal di SMPN 4 Tambang adalah sebagian besar siswa tidak dapat merespon pertanyaan dari guru, menyampaikan pendapatnya dan menanggapi pendapat teman karena kurangnya motivasi dalam pembelajaran, mereka beranggapan bahwa mata pelajaran fisika sulit, juga karena kurangnya keseriusan siswa dalam belajar dan mengerjakan soal-soal yang diberikan oleh guru.

Salah satu penyebab tidak tuntasnya pembelajaran disekolah adalah peran guru di kelas lebih dominan jika dibandingkan siswa. Pembelajaran yang didominasi oleh guru ini membuat siswa menjadi pasif dan kurang berpartisipasi. Inilah yang menyebabkan beberapa siswa mengalami kesulitan-kesulitan dalam menerima dan memahami konsepkonsep fisika dan menyebabkan keterampilan sosial siswa masih tergolong rendah.

Oleh sebab itu diperlukan suatu mekanisme pembelajaran yang dapat membangkitkan minat dan daya tarik siswa untuk belajar fisika hingga diharapkan akan berdampak baik pada hasil belajar siswa. Salah satu cara yang dapat ditempuh adalah dengan menerapkan model pembelajaran induktif.

Model pembelajaran berpikir induktif merupakan karya besar Hilda Taba. Suatu strategi mengajar yang dikembangkan untuk meningkatkan kemampuan siswa dalam mengolah informasi. Model berpikir induktif digunakan untuk meningkatkan efektivitas siswa dalam membangun konsep dan mengembangkan keterampilan untuk menyelesaikan tugas ( Joice \& Weil, 2011). Adapun langkah-langkah model pembelajaran induktif Taba adalah: 1) pembentukan konsep, 2) interpretasi data, dan 3) aplikasi prinsip.

Karakteristik yang dimiliki model pembelajaran induktif adalah: 1) digunakan untuk mengajarkan konsep dengan menggeneralisasi; 2) efektif untuk memotivasi siswa dalam pembelajaran; 3) menumbuhkan minat dan sikap siswa dalam melakukan observasi dan siswa diberi kesempatan untuk aktif; dan 4) mengembangkan keterampilan proses siswa dalam belajar. Untuk itulah model 
induktif ini dipilih dalam pembelajaran materi cahaya.

\section{METODE PENELITIAN}

Penelitian ini dilaksanakan di kelas VIII SMP Negeri 4 Tambang pada semester genap tahun ajaran 2010/2011 dengan subjek penelitian siswa kelas VIII.A yang berjumlah 34 siswa, terdiri dari 17 orang siswa perempuan dan 17 orang siswa laki-laki Penelitian ini adalah penelitian deskriptif kuantitatif karena dalam penelitian ini memaparkan (mendeskripsikan) keterampilan sosial siswa dalam pembelajaran fisika melalui penerapan model induktif untuk empat kali pertemuan.

Langkah-langkah yang dilakukan dalam penelitian ini adalah menentukan 11 orang siswa yang diamati dengan mengambil secara acak 2 dari 6 kelompok yang telah dilakukan uji homogenitas dan normalitas sebelumnya, melaksanakan pembelajaran sesuai dengan RPP, mengamati keterampilan social yang muncul selama proses pembelajaran berlangsung, dan menganalisis hasil pengamatan keterampilan social siswa.

Instrumen penelitian ini terdiri dari perangkat pembelajaran dan instrumen pengumpulan data. Perangkat pembelajaran yang digunakan yaitu silabus, RPP, dan LKS. Sedangkan instrument pengumpul datanya adalah lembar pengamatan keterampilan sosial siswa. Keterampilan sosial yang diamati meliputi aspek indikator (1) bekerja sama; (2) menyampaikan pendapat; (3) menanggapi pendapat; dan (4) mendengarkan dengan aktif.

Teknik pengumpulan data keterampilan sosial adalah pengamatan langsung dengan cara mengisi lembar (observasi) sesuai dengan aspek-aspek yang ditetapkan pada kolom yang tersedia. Dalam penelitian ini dilakukan oleh satu orang pengamat. Pengamatan terhadap keterampilan sosial dilakukan pada saat proses pembelajaran berlangsung untuk empat kali pertemuan.

Untuk menganalisis data keterampilan sosial yang diperoleh digunakan teknik deskriptif dengan langkah- langkah (1) memberi skor antara 1-4 pada saat mengamati setiap keterampilan sosial siswa yang muncul sesuai indikator; (2) menjumlahkan skor yang diperoleh siswa; (3) menghitung persentase perubahan keterampilan sosial siswa pada tiap indikator; dan (4) menentukan kategori keterampilan sosial setiap siswa.

\section{HASIL DAN PEMBAHASAN}

Setelah dilakukan penelitian sesuai dengan langkah-langkah yang telah ditetapkan sebelumnya, diperolehlah data hasil pengamatan keterampilan sosisal siswa. Secara umum hasil pengamatan indikator keterampilan sosial siswa pada setiap pertemuan dapat dilihat pada tabel 1.

Tabel 1. Hasil Pengamatan Keterampilan Sosial Siswa Tabel

\begin{tabular}{|l|c|c|c|c|}
\hline \multirow{2}{*}{ Indikator } & \multicolumn{4}{|c|}{ Pertemuan ke- } \\
\cline { 2 - 5 } & $\begin{array}{c}\mathbf{1} \\
(\boldsymbol{\%})\end{array}$ & $\begin{array}{c}\mathbf{2} \\
(\boldsymbol{\%})\end{array}$ & $\begin{array}{c}\mathbf{3} \\
(\boldsymbol{\%})\end{array}$ & $\begin{array}{c}\mathbf{4} \\
(\boldsymbol{\%})\end{array}$ \\
\hline Bekerja sama & 93.18 & 100 & 95.4 & 100 \\
& & & 5 & \\
\hline $\begin{array}{l}\text { Menyampaikan } \\
\text { pendapat }\end{array}$ & 81.81 & $\begin{array}{c}63.6 \\
93.1\end{array}$ & 86.63 \\
\hline $\begin{array}{l}\text { Menanggapi } \\
\text { pendapat }\end{array}$ & 29.54 & 47.7 & 84.0 & 72.72 \\
\hline $\begin{array}{l}\text { Mendengarkan } \\
\text { dengan aktif }\end{array}$ & 63.63 & $\begin{array}{c}88.6 \\
9\end{array}$ & $\begin{array}{c}95.4 \\
5\end{array}$ & 100 \\
\hline Rata-rata (\%) & 67.04 & 75.0 & 90.3 & 92.04 \\
\hline Kategori & $\mathrm{S}$ & $\mathrm{S}$ & $\mathrm{T}$ & $\mathrm{T}$ \\
\hline
\end{tabular}

Keterangan:

$\mathrm{S} \quad$ : Sedang

$\mathrm{T} \quad$ : Tinggi

Berdasarkan Tabel 3, pada pertemuan I dan II rata-rata siswa memiliki keterampilan sosial pada kategori sedang, pada pertemuan III dan IV siswa memiliki rata-rata keterampilan sosial pada kategori tinggi. Hasil pengamatan keterampilan sosial siswa selama proses pembelajaran mengalami peningkatan setiap pertemuan. Peningkatan yang paling tinggi adalah pada indicator bekerjasama dan mendengarkan dengan aktif.

Dengan menggunakan teknik analisis deskriptif pada lembar pengamatan keterampilan sosial siswa dari pertemuan 


\section{JURNAL KIPRAH, Juli 2018; VI1(1): 27-31 \\ e-ISSN: 2580-6947 \\ p-ISSN: 2354-7278}

pertama sampai pertemuan keempat dalam penerapan model induktif kelas VIII.a SMP Negeri 4 Tambang ini, maka diperoleh pembahasan untuk setiap indikator sikap ilmiah siswa sebagai berikut:

\section{Indikator Bekerja Sama}

Indikator bekerjasama yang diamati dalam penelitian ini adalah setiap anggota kelompok harus terlibat dalam mengerjakan dan mau berbagi tugas dengan anggota kelompok lainya. Setiap anggota kelompok diharapkan bisa bekerja sama dengan anggota kelompok lain serta memberikan kepercayaan kepada teman untuk mengerjakan tugas tertentu. Dengan adanya kerjasama yang baik dalam kelompok, tugas yang menjadi tanggung jawab masing-masing dapat diselesaikan dengan baik.

Pada pertemuan I sampai 4 indikator bekerja sama sudah terlaksana dengan baik, keempat pertemuan mencapai kategori tinggi artinya hampir semua descriptor yang diamati muncul bahkan di pertemuan kedua dan keempat semua descriptor yang diamati muncul. Hal ini disebabkan karena dalam proses pembelajaran guru secara aktif memimpin aktivitas pembelajaran, membuat siswa bersemangat dalam tugasnya dan membuat harapan yang positif bagi siswa. selain aktif terlibat dalam mengerjakan tugas kelompok, siswa juga saling membantu dalam mengerjakan tugas dan membagi tugas yang diberikan guru secara merata kesetiap anggota kelompok. Namun dalam pembelajaran khususnya pada pertemuan 1 dan 3 ada beberapa siswa yang belum berperan dalam mengerjakan tugas kelompok,. Secara umum keterampilan sosial siswa pada indikator bekerjasama dengan penerapan pembelajaran model induktif menunjukan hasil yang tinggi.

\section{Indikator Menyampaikan Pendapat}

Indikator menyampaikan pendapat yang diamati pada penelitian ini adalah ketika seorang siswa ingin menyampaikan pendapatnya, menggunakan bahasa yang jelas, artinya bahasa yang digunakan siswa dapat dimengerti oleh siswa lainya, kemudian santun dalam berbicara, ketika menyampaikan pendapat menggunakan kata-kata yang sopan dan menggunakan etika yang baik, serta relevan dengan topik yang sedang dibicarakan artinya pembicaraan tidak melebar dan keluar dari hal yang sedang dibicarakan.

Dari empat kali pertemuan yang dilakukan pada indikator menyampaikan pendapat menunjukan perolehan skor yang tidak terlalu jauh perbedaanya. Skor yang diperoleh siswa dalam pengamatan menunjukkan hasil dalam kategori tinggi dan sedang. Kategori tinggi diperoleh pada pertemuan 1,3 dan 4. Pada tiga pertemuan ini rata-rata semua siswa sudah berani menyampaikan pendapatnya, hanya saja ada beberapa orang yang belum relevan dengan topik yang sedang dibicarakan. Sementara kategori sedang terlihat pada pertemuan 2 perolehan persentase siswa hanya $63.63 \%$. Pada pertemuan ini semua siswa sudah berani menyampaikan pendapatnya denga bahasa yang jelas, namun tidak menunjukkan sikap yang santun dalam penyampaianya.

\section{Indikator menanggapi pendapat}

Deskriptor yang digunakan pada Indikator menanggapi pendapat yang diamati pada penelitian ini sama dengan deskriptor pada indikator menyampaikan pendapat, yaitu menggunakan bahasa yang jelas, santun dalam berbicara, dan relevan dengan topik yang sedang dibicarakan.

Pada kelas ini indikator menanggapi pendapat untuk empat kali pertemuan berkisar pada kategori rendah hingga tinggi. Pada pertemuan I persentase skor siswa sebesar 29.54\% berada pada kategori rendah, dapat dilihat ketika setiap kelompok mempresentasikan hasil diskusinya didepan kelas, pada pertemuan ini hanya satu orang yang menanggapi pendapat. Kategori tnggi terlihat pada pertemuan 3 dengan pesentase $84.09 \%$, pada pertemuan ini lingkungan belajar yang diciptakan guru sudah membuat 
siswa merasa bebas dan terlepas dari resiko takut dan malu saat memberikan pendapat, bertanya, membuat konklusi dan jawaban siswa aktif menanggapi pendapat teman. Menurut Eggen (1996) model induktif membutuhkan lingkungan kelas yang membuat siswa merasa bebas bertanggung jawab atas kesimpulannya tanpa merasa takut di kritik atau dipermalukan.

\section{Indikator mendengarkan dengan aktif}

Indikator mendengarkan dengan aktif yang dimaksud dalam penelitian ini adalah siswa dapat mendengarkan dan menunjukkan perhatian terhadap pendapat teman, mencatat yang penting dari informasi yang didapat, meminta penjelasan lanjut untuk hal-hal yang tidak dimengerti, dan menyatakan kesetujuan/tidak pada penjelasan atau pendapat teman. Ini membuktikan bahwa siswa antusias terhadap pelajaran yang disampaikan, menunjukkan perhatian, fokus mendengarkan pelajaran dan mengikuti seluruh intruksi yang diberikan. Ini dapat dilihat tidak hanya pada saat guru menyajikan materi, tetapi juga dilihat ketika teman menyampaikan pendapat.

persentase keterampilan sosial siswa untuk indikator mendengarkan dengan aktif yang diperoleh pada setiap pertemuan berkisar dari sedang hingga tinggi dan meningkat setiap pertemuannya, bahkan mencapai skor maksimal pada pertemuan 4. Pada pertemuan dengan kategori sedang dan persentase sebesar $63.63 \%$ siswa masih dalam indicator memperhatikan dan mencatat informasi, baru 1 orang yang memberikan tanggapan terhadap pendapat teman. Hal ini disebabkan karena siswa belum terbiasa dengan dan amsih merasa canggung untuk memulai. Barulah dipertemuan ke 4 semua siswa telah memenuhi deskriptor pada indikator mendengarkan dengan aktif yang ditetapkan peneliti yaitu perhatian dalam mendengar pendapat orang lain, membuat catatan serta menanggapi pendapat teman. Pada pertemuan ini tugas guru dalam mengaktifkan siswa saat kegiatan belajar mengajar berlangsung sudah tidak berat lagi karena siswa sudah terbiasa sejak pertemuan pertama

\section{KESIMPULAN}

Berdasarkan analisis deskriptif tentang keterampilan sosial siswa di kelas VIII.a SMP Negeri 4 Tambang, maka peneliti menyimpulkan bahwa keterampilan sosial siswa berada pada kategori sedang hingga tinggi dan meningkat tiap pertemuan saat penerapan model pembelajaran induktif. Dengan demikian dapat disimpulkan model induktif baik digunakan untuk meningkatkan keterampilan sosial siswa.

\section{REFERENSI}

Anderson, L.W dan Krathwohl, D.R. 2010. Kerangka Landasan untuk Pembelajaran, Pengajaran dan Asesmen (Revisi Taksonomi Pendidikan Bloom). Yogyakarta: Pustaka Pelajar.

Eggen, P.D. and Kauchak. D.P. 1996. Learning and Teaching. 2 nd ed. Needdham Height, Massachussets: Allyn and Bacon.

Joice, B \& Weil, M. (2011). Model of Teaching. Yogyakarta: Pustaka Pelajar.

Peraturan Pemerintah (PP) Nomor 19 Tahun 2005 tentang Standar Nasional Pendidikan (SNP)

Ratumanan, T.G. 2004. Belajar dan Pembelajar. Surabaya: UNESA University.

Sugiyono. (2008). Metode Penelitian Kuantitatif, Kualitatif, dan R\&D. Bandung: Alfabeta.

Trianto, (2007). Model-model Pembelajaran iInovatif berorientasi kontruktivistik. Prestasi Pustaka: Jakarta.

Undang-undang Republik Indonesia nomor 20 tahun 2003 tentang Sistem Pendidikan Nasional Bab I Pasal 1 Nomor 1. 